\title{
Fast and efficient direct conversion of 2-aminopyridine into 2,3-disubstituted imidazo[1,2-a]pyridines
}

\author{
Vanya B. Kurteva, ${ }^{\text {a,* }}$ Lubomir A. Lubenov, ${ }^{\text {a Daniela V. Nedeltcheva, }}{ }^{\text {a }}$ Rositsa P. Nikolova, \\ and Boris L. Shivachev \\ ${ }^{a}$ Institute of Organic Chemistry with Centre of Phytochemistry, Bulgarian Academy of Sciences, \\ Acad. G. Bonchev str., bl. 9, 1113 Sofia, Bulgaria \\ ${ }^{b}$ Institute of Mineralogy and Crystallography "Acad. Ivan Kostov”, Bulgarian Academy of \\ Sciences, Acad. G. Bonchev str., bl. 107, 1113 Sofia, Bulgaria
}

E-mail: vkurteva@orgchm.bas.bg

\begin{abstract}
A direct conversion of 2-aminopyridine into 2,3-disubstituted imidazo[1,2-a]pyridines was studied. A series of products was obtained in an efficient, simple and fast protocol. The scope and limitation of the transformation are also studied and was found that its effectiveness and the type of the substituent at 3-position, 3-(1-arylethane) and/or 3-(1-arylethene), is strongly dependent both on the catalyst and on the ketone aromatic substituent. The structures of the products were assigned by 1D and 2D NMR spectra and confirmed by X-ray analyses of selected samples.
\end{abstract}

Keywords: Imidazo[1,2-a]pyridines, 3-(1-arylethane) substituted, 3-(1-arylethene) substituted, NMR, X-ray

\section{Introduction}

Imidazo[1,2- $a$ ]pyridines are a class of $N$-bridged fused bicyclic compounds, which attracted significant attention in recent years due to the broad spectrum of pharmacological profiles displayed. For instance, such molecules have exhibited antiviral, ${ }^{1}$ antimicrobial, ${ }^{2}$ antitumor, ${ }^{3}$ anti-inflammatory, ${ }^{4}$ antiparasitic, ${ }^{5}$ hypnotic, ${ }^{6}$ and many other activities. In general, these profiles are shown to be strongly dependent on the nature of substituents at 2 and 3 positions. $^{7}$

A number of methods have been developed for the synthesis of this important framework; the most exploiting 2-aminopyridine as starting material. The main part of the protocols involves initial coupling reactions between endocyclic nitrogen of 2-aminopyridine and various reagents, such as $\alpha$-halocarbonyl compounds, ${ }^{8}$ diazoketones, ${ }^{9}$ oxothioamide, ${ }^{10}$ 1,2-diols, ${ }^{11}$ 1chloromethylbenzotriazole, ${ }^{12}$ 1,2-bis(benzotriazolyl)-1,2-(dialkylamino)-ethanes, ${ }^{13}$ followed by cyclization with the exocyclic amino group. However, these approaches generally suffer from 
such drawbacks as low yields and difficultly obtainable starting materials involving tedious workup procedures. More versatile procedures, allowing efficient preparation of compounds with variable substitution patterns, involve multi-component coupling transformations of 2aminopyridine with aldehyde and unsaturated reagents, like isocyanides, ${ }^{14}$ nitrile, $^{15}$ thyocyanates, ${ }^{16}$ alkynes, ${ }^{17}$ etc.

The reversed sequence, initial attack on the much less reactive exocyclic amino group and subsequent interaction with the endocyclic nitrogen, has also been applied. Whereas the reaction with aldehydes leading to 3 -substituted products via aldimines is poorly studied, ${ }^{18}$ to the best of our knowledge, no records describe the preparation of 2,3-disubstituted compounds via ketimines.

Herein, we present a fast and simple efficient protocol for direct conversion of 2aminopyridine into 2,3-substituted imidazo[1,2-a]pyridines. The scope and limitation of the transformation are also discussed.

\section{Results and Discussion}

A direct conversion of 2-aminopyridine into 2,3-disubstituted imidazo[1,2-a]pyridines was studied. A set of acetophenones was chosen in an attempt to examine the influence of different type of substituents on the transformation. Harsh conditions were applied in order to override the low reactivity of the exocyclic nitrogen. Numerous procedures for azomethine synthesis were tested with acetophenone, such as azeotropic distillation with Dean-Stark trap or in the presence of various watertrapping agents or catalysts. Insufficient results were obtained in all cases; up to $16 \%$ yields of imidazopyridine $\mathbf{3 a}$, in parallel with the corresponding azomethine and starting materials. Finally, effective conversion was achieved by using 5-fold excess of ketone in a solvent-free protocol at $200-220^{\circ} \mathrm{C}$ in the presence of an acid catalyst. The efficiency of various acids was checked and was found that acetic and trifluoroacetic acid do not catalyze the transformation significantly, while $p$-toluenesulfonic and sulfuric acid lead to considerable conversion of 2-aminopyridine to 3a. As shown on Scheme 1, three types of imidazopyridines differing at the substitution at 3-position were obtained depending both on the catalyst and on the ketone aromatic substituents.

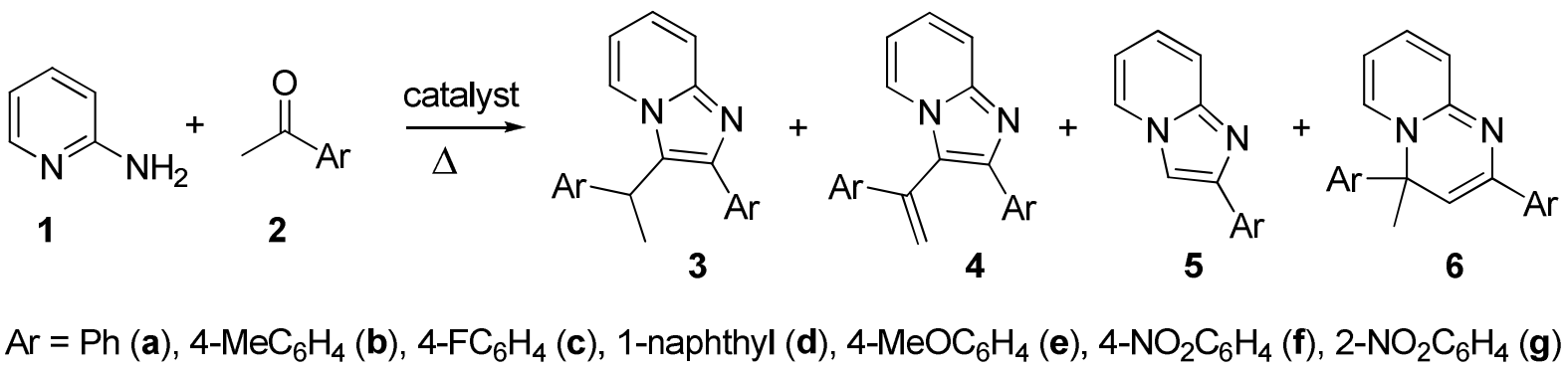

Scheme 1. Synthesis of imidazo[1,2-a]pyridines. 
As seen on Table 1, good conversions, 70-79\%, were achieved in $p$-toluenesulfonic acid catalyzed reaction with acetophenone (entry 1), 4-methylacetophenone (entry 3) and 4fluoroacetophenone (entry 4). The transformation proceeded very fast and clean, only single products and staring ketones were detected by TLC within 30-45 min. The compounds were easily purified by chromatography due to the substantial differences between their $\mathrm{R}_{\mathrm{f}}$-values and those of the ketones. The recovered acetophenones can be efficiently reused, which represent an additional advantage of the protocol. Contrary to $p$-toluenesulfonic acid catalyzed reaction, the sulfuric acid catalyzed transformation of acetophenone (entry 2) led to a mixture of imidazopyridines $\mathbf{3 a}$ and $\mathbf{4 a}$ in excellent total yield.

Table 1. Synthesis of imidazo[1,2- $a$ ]pyridines $\mathbf{3}, \mathbf{4}$ and $\mathbf{5}$ and pyrido[1,2-a]pyrimidine $\mathbf{6}$

\begin{tabular}{|c|c|c|c|c|c|c|c|c|}
\hline \multirow{2}{*}{ Entry } & \multirow{2}{*}{ Ar } & \multirow{2}{*}{ Catalyst } & \multirow{2}{*}{$\begin{array}{c}\text { Tempera } \\
\text { ture, }{ }^{\circ} \mathrm{C}\end{array}$} & \multirow{2}{*}{$\begin{array}{l}\text { Reaction } \\
\text { time, min }\end{array}$} & \multicolumn{4}{|c|}{ Product, $\%$ isolated yield } \\
\hline & & & & & 3 & 4 & 5 & 6 \\
\hline 1 & $\mathrm{Ph}$ & $p$-TSA & 210 & 45 & 76 & - & - & - \\
\hline 2 & $\mathrm{Ph}$ & $\mathrm{H}_{2} \mathrm{SO}_{4}$ & 210 & 30 & 70 & 17 & - & - \\
\hline 3 & $4-\mathrm{MeC}_{6} \mathrm{H}_{4}$ & $p$-TSA & 220 & 30 & 79 & - & - & - \\
\hline 4 & $4-\mathrm{FC}_{6} \mathrm{H}_{4}$ & $p$-TSA & 200 & 45 & 70 & - & - & - \\
\hline 5 & 1-naphthyl & $p$-TSA & 220 & 45 & 39 & - & - & - \\
\hline 6 & 1-naphthyl & $p$-TSA & 300 & 30 & 48 & - & - & - \\
\hline 7 & $4-\mathrm{OMeC}_{6} \mathrm{H}_{4}$ & $p$-TSA & 200 & 30 & 6 & - & - & - \\
\hline 8 & $4-\mathrm{OMeC}_{6} \mathrm{H}_{4}$ & $p$-TSA & 220 & 30 & 23 & 14 & 28 & - \\
\hline 9 & $4-\mathrm{OMeC}_{6} \mathrm{H}_{4}$ & $\mathrm{H}_{2} \mathrm{SO}_{4}$ & 200 & 30 & 13 & 10 & 13 & - \\
\hline 10 & $4-\mathrm{NO}_{2} \mathrm{C}_{6} \mathrm{H}_{4}$ & $p$-TSA & 150 & 50 & - & - & - & 4 \\
\hline 11 & $4-\mathrm{NO}_{2} \mathrm{C}_{6} \mathrm{H}_{4}$ & $\mathrm{H}_{2} \mathrm{SO}_{4}$ & 200 & 15 & - & 10 & - & - \\
\hline
\end{tabular}

The reaction with sterically hindered aceto-1-naphthone led to $\mathbf{3 d}$ formation as a sole product when $p$-toluenesulfonic acid was used, while complex mixture was obtained with sulfuric acid. The reaction conditions were varied and were found that higher temperature is required to override the steric factor; $39 \%$ yield of 3d after $45 \mathrm{~min}$ heating at $220{ }^{\circ} \mathrm{C} \mathrm{vs} 48 \%$ after 30 min heating at $300{ }^{\circ} \mathrm{C}$ (entry 5 vs entry 6).

In the case of 4-methoxyphenyl ketone, complex reaction mixtures were formed. The conditions were varied and were found that no conversion occurred at $150{ }^{\circ} \mathrm{C}$ even after $2-4 \mathrm{~h}$. Methoxy derivative 3e was obtained as a sole product, although in very poor yield (entry 7 ), after heating at $200{ }^{\circ} \mathrm{C}$ in the presence of $p$-toluenesulfonic acid in consecutive 15 min intervals in a pear-shaped flask. When increased the temperature to $220{ }^{\circ} \mathrm{C}$ (entry 8) or used round bottom flask, 3e was obtained in better yield but together with two additional compounds, which structures were assigned by NMR spectra as 3-(1-arylethene) substituted imidazopyridine 4e and monosubstituted product 5e (Scheme 1). The same mixture was obtained by using sulfuric acid but in lower total yield (entry 9). 
The experiments with nitroacetophenones showed that these ketones are not proper starting substrates for the transformation studied. No conversion was detected bellow $120{ }^{\circ} \mathrm{C}$, while very complex reaction mixtures were obtained at higher temperatures in general, which separation was not reasonable. Successful transformation with 2-nitroacetophenone was not achieved in the presence of various catalysts, while pyridopyrimidine $6 \mathbf{f}$ (entry 10) or 3-(1-arylethene) substituted imidazopyridine $\mathbf{4 f}$ (entry 11 ) were formed as single products in very poor yields from 4-nitroacetophenone by using $p$-toluenesulfonic acid at $150{ }^{\circ} \mathrm{C}$ or sulfuric acid at $200{ }^{\circ} \mathrm{C}$, respectively.

The structures of the products were assigned on the bases of the characteristic proton and carbon resonances in the NMR spectra and were confirmed by 2D experiments and crystallography analysis of selected samples. ${ }^{19}$ The NMR spectra of imidazo[1,2- $a$ ]pyridines 3 show a doublet for a methyl group, $\mathrm{CH}$ neighbour to $\mathrm{CH}_{3}$, and a quaternary carbon at 123-125 ppm. The vinylated products 4 show characteristic signals for a terminal $\mathrm{C}=\mathrm{CH}_{2}$, while $\mathbf{5 e}$ shows an additional singlet for aromatic $\mathrm{CH}$, no $\mathrm{CH}-\mathrm{CH}_{3}$ and only one 4-methoxyphenyl group. The observed significant upfielding of $\mathrm{CH}-5$ in the proton NMR spectra of compounds 3 and $\mathbf{4}$ in respect to monosubstituted product 5e (Figure 1), can be explained by conformation with aromatic substituent at position 3 orientated towards the pyridinium ring, where $\mathrm{CH}-5$ lies in the shielding zone of Ar-3. The spectra of pyrido[1,2-a]pyrimidine $6 \mathbf{f}$ show a singlet for a methyl group, an additional singlet for aromatic $\mathrm{CH}$ and a quaternary carbon at $65 \mathrm{ppm}$.
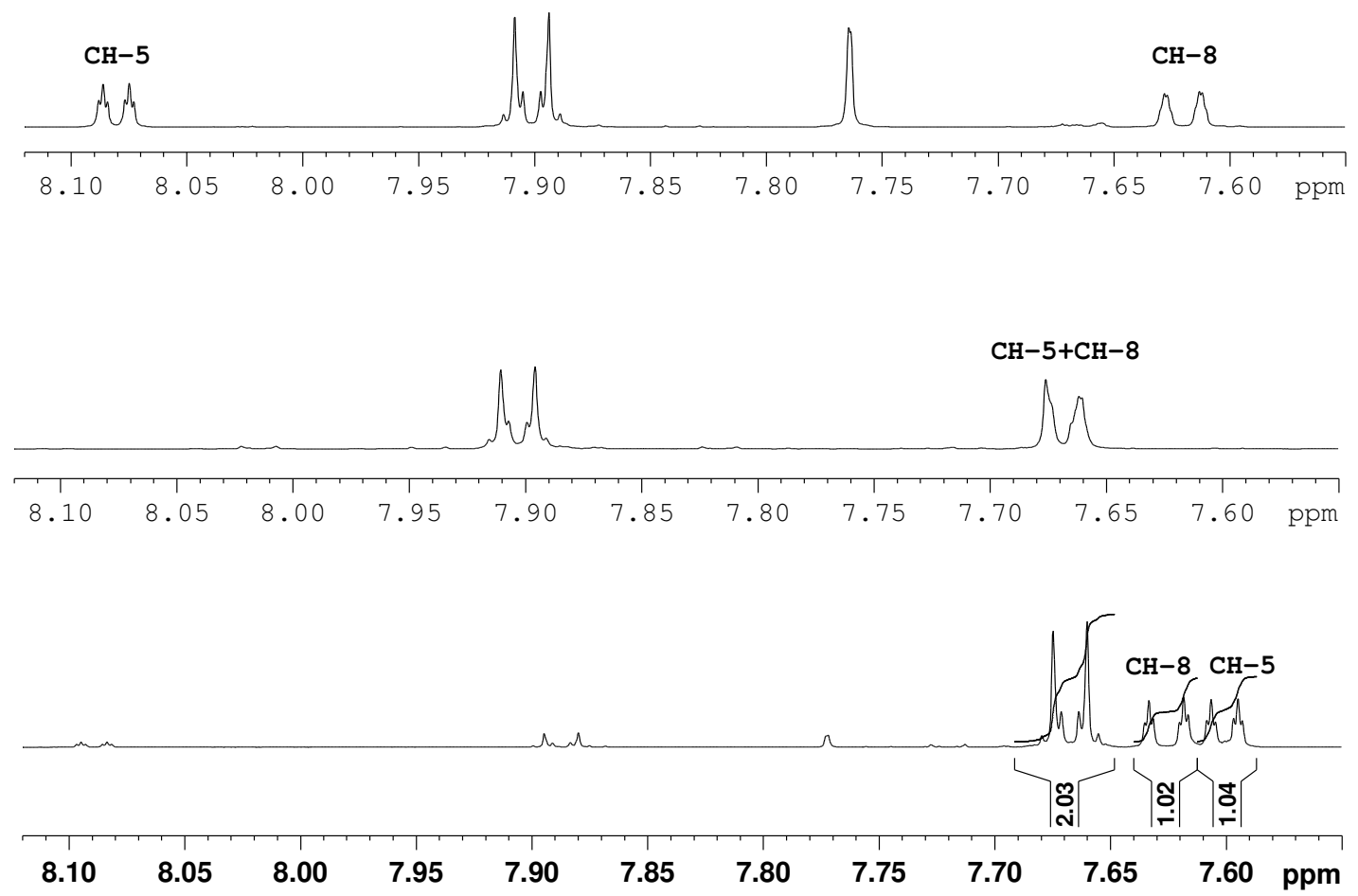

Figure 1. Partial proton spectra of $\mathbf{3 e}$ (down), $\mathbf{4 e}$ (middle), and 5e (up). 
The structures of the products $3 \mathbf{a}, \mathbf{4 a}$ and $5 \mathbf{e}$ were fully elucidated by X-ray diffraction methods (Table S1). ${ }^{19}$ An ORTEP view of $\mathbf{3 a}$ is reported on Figure 2 together with the atomic labeling scheme. The crystals of compound contain two independent molecules in the asymmetric unit. The main structural dissimilarity between them relates to the positioning of the phenyl from the substituent at the 3 position, which is clearly demonstrated by the overlay of the two molecules shown on Figure 3 a.

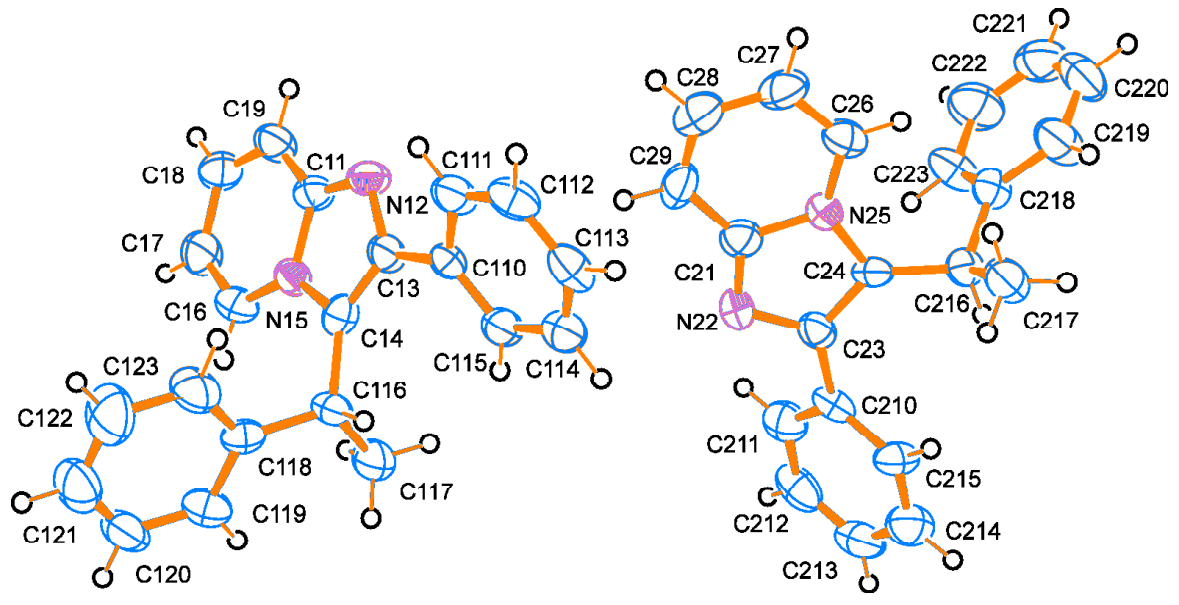

Figure 2. ORTEP view of 3a with the atomic numbering scheme; ellipsoids are drawn at 50\% probability, hydrogen atoms are shown as small spheres with arbitrary radii.

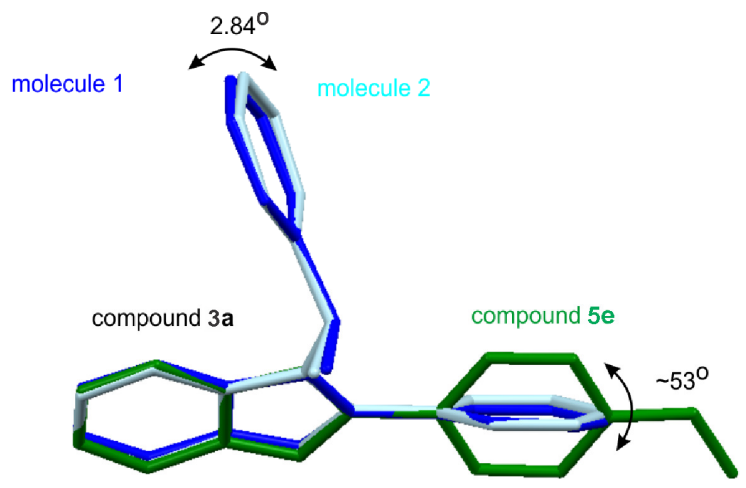

a)

Figure 3. Overlay of the two independent molecules in the asymmetric unit of: a) 3a and 5e; a dark blue molecule 1 and a light blue molecule 2 of $\mathbf{3 a}$ and a green molecule of $\mathbf{5 e}$; b) $4 \mathbf{a}$; a green molecule 1 and a blue molecule 2 .

The structure of 3-(1-arylethene) substituted imidazo[1,2-a]pyridines 4 was confirmed by Xray analysis of 4a. An ORTEP view of the molecule is reported on Figure 4 together with the atomic labeling scheme. Compound $\mathbf{4 a}$ crystallizes also with two independent molecules in the 
asymmetric unit. As in 3a, the dissimilarity between the two molecules of $\mathbf{4 a}$ is associated to the rotation of the phenyl along C13-C110/C23-C210 (Figure 3b).
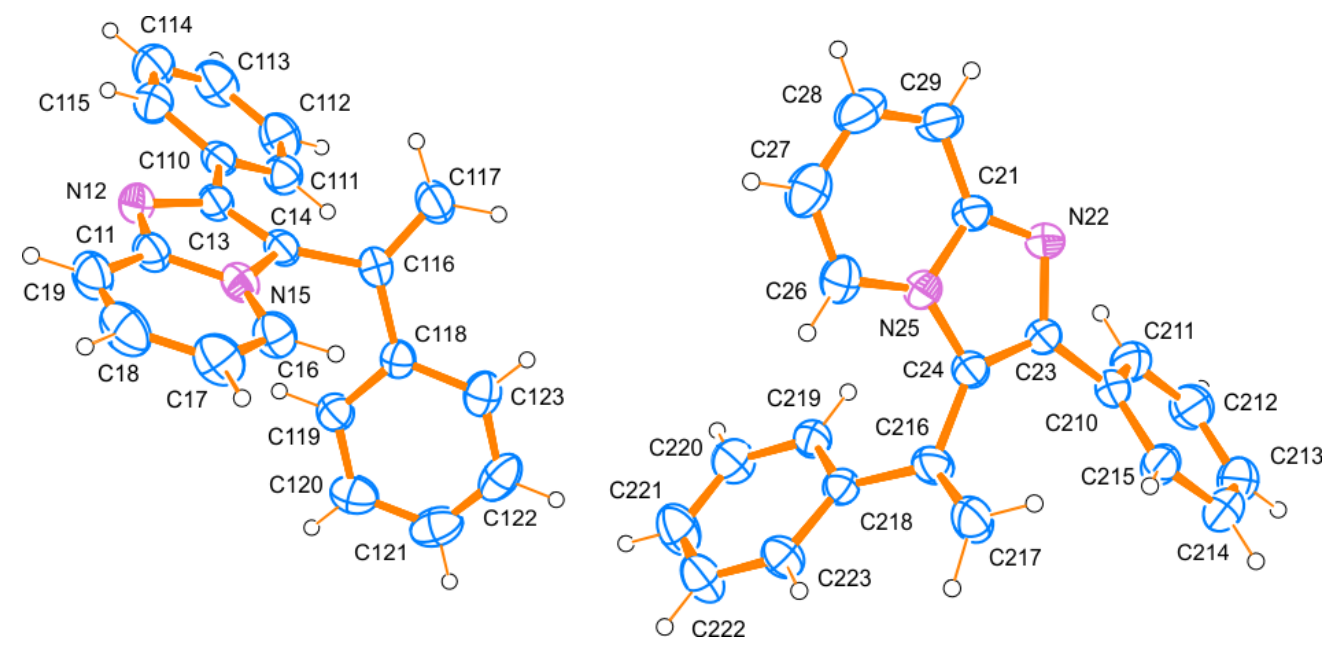

Figure 4. ORTEP view of $\mathbf{4 a}$ with the atomic numbering scheme; ellipsoids are drawn at $50 \%$ probability, hydrogen atoms are shown as small spheres with arbitrary radii.

Compound 5e crystallizes with one independent molecule in the asymmetric unit. An ORTEP view of the molecule is reported on Figure 5 together with the atomic labeling scheme. The main structural dissimilarity between compounds 3a and $\mathbf{5 e}$ relates to the positioning of the 2-phenyl with respect to the imidazo[1,2-a]pyridine one (Figure 3a).

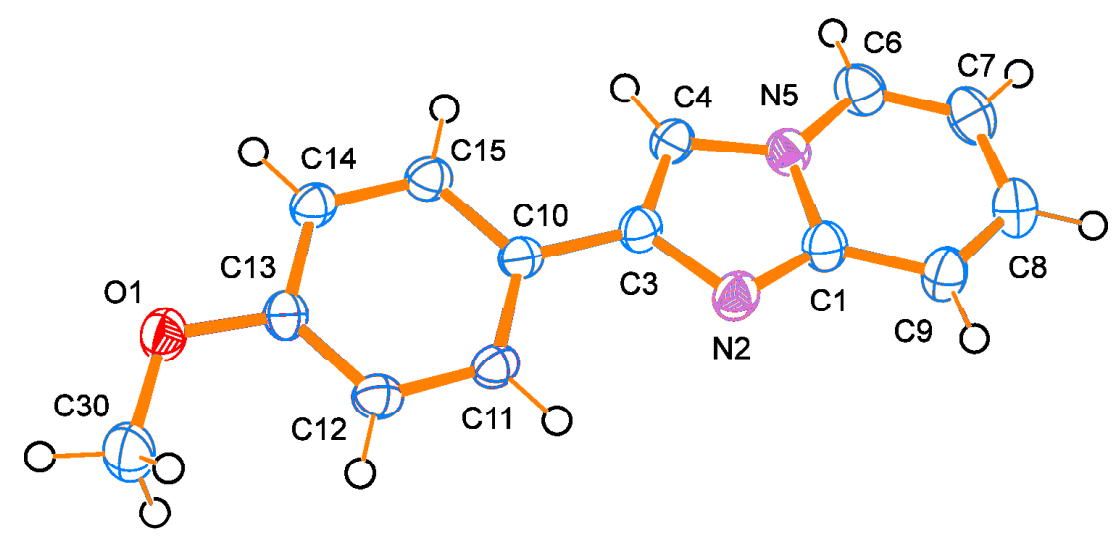

Figure 5. ORTEP view of 5e with the atomic numbering scheme; ellipsoids are drawn at 50\% probability, hydrogen atoms are shown as small spheres with arbitrary radii. 


\section{Conclusions}

A direct conversion of 2-aminopyridine into 2,3-substituted imidazo[1,2-a]pyridines was studied. A series of products was obtained in an efficient, simple and fast protocol; 30-50 min heating in solventless conditions. The scope and limitation of the transformation are also studied and was found that its effectiveness and the type of the substituent at 3-position is strongly dependent both on the catalyst and on the ketone aromatic substituent. The $p$-toluenesulfonic acid catalyzed reaction of acetophenones without or with electrodonating substituents (acetophenone, 4methylacetophenone, 4-fluoroacetophenone, and aceto-1-naphthone) resulted in 3-(1-arylethane) substituted imidazo pyridines as sole products in good yields. Contrary, the sulfuric acid catalyzed reaction led to excellent conversion but a mixture of 3-(1-arylethane) and 3-(1arylethene) products were obtained. In the case of 4-methoxyacetophenone, both catalysts generated a mixture of products; 3-(1-arylethane) 3e, 3-(1-arylethene) 4e and unsubstituted at 3position imidazopyridine 5e; conversion being better with $p$-toluenesulfonic acid. With ketones possessing an electrowithdrawing substituent, 4-nitroacetophenone and 2-nitroacetophenone, successful conversion was achieved only in the first case. The 3-(1-arylethene) substituted imidazo[1,2-a]pyridine $\mathbf{4 f}$ was obtained via sulfuric acid catalyzed reaction, while 2,4,4trisubstituted pyrido[1,2-a]pyrimidine $6 \mathbf{f}$ was isolated when $p$-toluenesulfonic acid was used; both as single products in poor yields.

\section{Experimental Section}

\section{Synthesis}

All reagents were purchased from Aldrich, Merck and Fluka and were used without any further purification. Fluka silica gel/TLC-cards 60778 with fluorescent indicator $254 \mathrm{~nm}$ were used for TLC chromatography and $\mathrm{R}_{\mathrm{f}}$-values determination. Merck Silica gel $60(0.040-0.063 \mathrm{~mm})$ was used for flash chromatography purification of the products. The melting points were determined in capillary tubes on SRS MPA100 OptiMelt (Sunnyvale, CA, USA) automated melting point system. The NMR spectra were recorded on a Bruker Avance II+ 600 spectrometer (Rheinstetten, Germany) at $25{ }^{\circ} \mathrm{C}$; the chemical shifts were quoted in ppm in $\delta$-values against tetramethylsilane (TMS) as an internal standard and the coupling constants were calculated in $\mathrm{Hz}$. The assignment of the signals was confirmed by applying 2D techniques. The spectra were recorded as $10^{-1} \mathrm{M}$ solutions in deuterochloroform except NOESY experiments where $3 \times 10^{-2} \mathrm{M}$ solutions were used in order to avoid transmolecular interactions. The low resolution mass spectra were taken on a HP 5973 Mass Selective Detector, the high resolution mass spectra on a DFS High Resolution Magnetic Sector MS, Thermo Scientific.

\section{Typical procedure}

A mixture of 2-aminopyridine ( $1 \mathrm{mmol})$, acetophenone $(5 \mathrm{mmol})$, and $p$-toluenesulphonic acid $(10 \mathrm{mg})$ or sulfuric acid $(0.1 \mathrm{ml})$ was heated at $150-300{ }^{\circ} \mathrm{C}$ for $30-50 \mathrm{~min}$. The products were 
purified by flash chromatography on silica gel by using mobile phase with a gradient of polarity from $\mathrm{CH}_{2} \mathrm{Cl}_{2}$ to acetone: $\mathrm{CH}_{2} \mathrm{Cl}_{2}$ :hexane 2:10:10. The results are summarized on Table 1 .

2-Phenyl-3-(1-phenylethyl)imidazo[1,2-a]pyridine (3a). $\mathrm{R}_{\mathrm{f}} 0.27$ (acetone: $\mathrm{CH}_{2} \mathrm{Cl}_{2}$ 5:95); mp 115.5-115.7 ${ }^{\circ} \mathrm{C} .{ }^{1} \mathrm{H}$ NMR 1.841 (d, 3H, J 7.4, $\mathrm{CH}_{3}$ ), 5.048 (q, 1H, J 7.4, $\mathrm{CH}-\mathrm{CH}_{3}$ ), 6.592 (td, 1H, $J$ 1.2, 6.9, CH-6), 7.140 (ddd, $1 \mathrm{H}, J 1.1,6.9,9.0, \mathrm{CH}-7), 7.269$ (m, 3H, CH-2, CH-4 and $\mathrm{CH}-6$ of Ph-3), 7.339 (tt, 2H, J 1.9, 7.2, CH-3 and $\mathrm{CH}-5$ of Ph-3), 7.403 (tt, 1H, J 1.9, 7.4, CH-4 of Ph-2), 7.483 (tt, 2H, J 1.6, 7.0, CH-3 and $\mathrm{CH}-5$ of Ph-2), 7.627 (dt, $1 \mathrm{H}, J$ 1.1, 6.9, CH-5), 7.679 (dt, 1H, $J$ 1.2, 9.0, $\mathrm{CH}-8), 7.778\left(\mathrm{dt}, 2 \mathrm{H}, J\right.$ 1.4, 6.9, $\mathrm{CH}-2$ and $\mathrm{CH}-6$ of Ph-2). ${ }^{13} \mathrm{C} \mathrm{NMR} 16.70\left(\mathrm{CH}_{3}\right)$, $33.78\left(\mathrm{CH}_{-} \mathrm{CH}_{3}\right), 111.56(\mathrm{CH}-6), 117.78(\mathrm{CH}-8), 122.96\left(\mathrm{C}_{\text {quat }}-3\right), 123.74(\mathrm{CH}-7), 124.53(\mathrm{CH}-$ 5), 126.61 ( $\mathrm{CH}-4$ of Ph-3), 126.80 ( $\mathrm{CH}-2$ and $\mathrm{CH}-6$ of Ph-3), 127.68 ( $\mathrm{CH}-4$ of Ph-2), 128.42 (CH-3 and $\mathrm{CH}-5$ of Ph-2), 128.81 ( $\mathrm{CH}-3$ and $\mathrm{CH}-5$ of $\mathrm{Ph}-3), 128.92(\mathrm{CH}-2$ and $\mathrm{CH}-6$ of $\mathrm{Ph}-2)$, $135.02\left(C_{\text {quat }}-1\right.$ of Ph-2), 141.11 ( $C_{\text {quat }}-1$ of Ph-3), $143.76\left(C_{\text {quat }}-2\right), 144.86\left(C_{\text {quat }}-9\right)$; HRMS (EI): calcd. for $\mathrm{C}_{21} \mathrm{H}_{18} \mathrm{~N}_{2}\left(\mathrm{M}^{+}\right)$298.1464, found 298.1466, 0.4 ppm error.

2-(4-Methylphenyl)-3-(1-(4-methylphenyl)ethyl)imidazo[1,2-a]pyridine $\quad(3 \mathrm{~b}) . \quad \mathrm{R}_{\mathrm{f}} \quad 0.27$ (acetone: $\mathrm{CH}_{2} \mathrm{Cl}_{2}$ 5:95); mp 128.1-128.4 ${ }^{\circ} \mathrm{C} .{ }^{1} \mathrm{H} \mathrm{NMR} 1.691$ (d, 3H, J 7.4, $\mathrm{CH}_{3}$ ), 2.230 (s, 3H, $\mathrm{CH}_{3}$ of 4-MePh-3), 2.315 (s, 3H, $\mathrm{CH}_{3}$ of 4-MePh-2), 4.889 (q, 1H, J 7.4, $\mathrm{CH}-\mathrm{CH}_{3}$ ), 6.463 (td, $1 \mathrm{H}, J$ 1.1, 6.8, CH-6), 7.025 (m, 5H, CH-7 and $\mathrm{CH}$ of 4-MePh-3), 7.174 (d, 2H, J 7.9, CH-3 and $\mathrm{CH}-5$ of 4-MePh-2), 7.515 (dt, $1 \mathrm{H}, J$ 1.1, 7.0, $\mathrm{CH}-5), 7.555(\mathrm{~m}, 3 \mathrm{H}, \mathrm{CH}-8$ and $\mathrm{CH}-2$ and $\mathrm{CH}-6$ of 4-MePh-2). ${ }^{13} \mathrm{C}$ NMR $16.75\left(\mathrm{CH}_{3}\right), 20.95\left(\mathrm{CH}_{3}\right.$ of $\left.4-\mathrm{MePh}-3\right), 21.29\left(\mathrm{CH}_{3}\right.$ of $\left.4-\mathrm{MePh}-2\right), 33.49$ $\left(\mathrm{CH}-\mathrm{CH}_{3}\right), 111.45(\mathrm{CH}-6), 117.71(\mathrm{CH}-8), 122.96\left(\mathrm{C}_{\text {quat }}-3\right), 123.61(\mathrm{CH}-7), 124.64(\mathrm{CH}-5)$, 126.74 ( $\mathrm{CH}-2$ and $\mathrm{CH}-6$ of 4-MePh-3), 128.82 ( $\mathrm{CH}-2$ and $\mathrm{CH}-6$ of 4-MePh-2), $129.18(\mathrm{CH}-3$ and $\mathrm{CH}-5$ of 4-MePh-2), $129.52\left(\mathrm{CH}-3\right.$ and $\mathrm{CH}-5$ of 4-MePh-3), 132.18 ( $C_{\text {quat }}-1$ of 4-MePh-2), 136.16 ( $C_{\text {quat }}-4$ of $\left.4-\mathrm{MePh}-3\right), 137.43\left(C_{\text {quat }}-4\right.$ of $\left.4-\mathrm{MePh}-2\right), 138.12\left(C_{\text {quat }}-1\right.$ of $\left.4-\mathrm{MePh}-3\right)$, $143.74\left(C_{\text {quat }}-2\right)$, $144.83\left(C_{\text {quat }}-9\right)$; HRMS (EI): calcd. for $\mathrm{C}_{23} \mathrm{H}_{22} \mathrm{~N}_{2}\left(\mathrm{M}^{+}\right) 326.1783$, found 326.1786, 0.9 ppm error.

2-(4-Fluorophenyl)-3-(1-(4-fluorophenyl)ethyl)imidazo[1,2-a]pyridine $\quad(3 \mathrm{c}) . \quad \mathrm{R}_{\mathrm{f}} \quad 0.29$ (acetone: $\mathrm{CH}_{2} \mathrm{Cl}_{2}$ 5:95); mp 164.2-164.6 ${ }^{\circ} \mathrm{C}$. ${ }^{1} \mathrm{H}$ NMR 1.800 (d, 3H, $J$ 7.4, $\mathrm{CH}_{3}$ ), 4.900 (q, 1H, $J$ 7.4, $\mathrm{CH}-\mathrm{CH}_{3}$ ), 6.611 (td, $\left.1 \mathrm{H}, \mathrm{J} 1.1,6.8, \mathrm{CH}-6\right), 6.998\left(\mathrm{ddd}, 2 \mathrm{H}, \mathrm{J}_{35} 2.1, \mathrm{~J}_{23} 8.6, \mathrm{~J}_{3 \mathrm{~F}} 8.8, \mathrm{CH}-3\right.$ and $\mathrm{CH}-5$ of 4-FPh-3), 7.145 (m, 3H, CH-7 and $\mathrm{CH}-3$ and $\mathrm{CH}-5$ of 4-FPh-2), 7.180 (ddd, $2 \mathrm{H}, J_{26}$ 0.9, $J_{2 \mathrm{~F}} 5.2, \mathrm{~J}_{23} 8.6, \mathrm{CH}-2$ and $\mathrm{CH}-6$ of 4-FPh-3), 7.577 (dt, $\left.1 \mathrm{H}, J 1.1,7.0, \mathrm{CH}-5\right), 7.642$ (dt, $1 \mathrm{H}, J$ 1.1, 9.0, $\mathrm{CH}-8$ ), 7.673 (ddd, $2 \mathrm{H}, \mathrm{J}_{26} 2.2, \mathrm{~J}_{2 \mathrm{~F}} 5.4, \mathrm{~J}_{23} 8.8, \mathrm{CH}-2$ and $\mathrm{CH}-6$ of 4-FPh-2). ${ }^{13} \mathrm{C}$ NMR $17.04\left(\mathrm{CH}_{3}\right), 33.27\left(\mathrm{CH}-\mathrm{CH}_{3}\right), 111.92(\mathrm{CH}-6), 115.52\left(\mathrm{~d}, \mathrm{~J}_{3 \mathrm{~F}} 21.4, \mathrm{CH}-3\right.$ and $\mathrm{CH}-5$ of $\left.4-\mathrm{FPh}-2\right)$, $115.74\left(\mathrm{~d}, J_{3 \mathrm{~F}} 21.3, \mathrm{CH}-3\right.$ and $\mathrm{CH}-5$ of $\left.4-\mathrm{FPh}-3\right), 117.87(\mathrm{CH}-8), 122.62\left(C_{\text {quat }}-3\right), 124.14(C \mathrm{H}-$ 7), 124.39 (CH-5), 128.36 (d, $J_{2 \mathrm{~F}} 7.8, C H-2$ and $C H-6$ of 4-FPh-3), 130.60 (d, $J_{2 \mathrm{~F}} 8.1, C H-2$ and CH-6 of 4-FPh-2), 131.00 (d, $J_{1 \mathrm{~F}} 3.0, C_{\text {quat }}-1$ of 4-FPh-2), 136.64 (d, $J_{1 \mathrm{~F}} 3.1, C_{\text {quat }}-1$ of 4-FPh-3), $142.86\left(C_{\text {quat }}-2\right), 144.90\left(C_{\text {quat }}-9\right), 161.62\left(\mathrm{~d}, J_{4 \mathrm{~F}} 246.2, C_{\text {quat }}-4\right.$ of $\left.4-\mathrm{FPh}-3\right), 162.62\left(\mathrm{~d}, J_{4 \mathrm{~F}} 246.7\right.$, $C_{\text {quat }}-4$ of 4-FPh-2); HRMS (EI): calcd. for $\mathrm{C}_{21} \mathrm{H}_{16} \mathrm{~F}_{2} \mathrm{~N}_{2}\left(\mathrm{M}^{+}\right)$334.1276, found 334.1276, -0.2 ppm error.

2-(Naphthalen-1-yl)-3-(1-(naphthalen-1-yl)ethyl)imidazo[1,2-a]pyridine $\quad(3 \mathrm{~d}) . \quad \mathrm{R}_{\mathrm{f}} \quad 0.35$ (acetone: $\mathrm{CH}_{2} \mathrm{Cl}_{2}$ 5:95); mp 162.4-162.7 ${ }^{\circ} \mathrm{C}$; For simplicity, naphthyl group in NMR spectra is 
assigned as Npt. Due to very closed or overlapped signals some interactions in 2D spectra are questionable; only the clear cross peaks are given. ${ }^{1} \mathrm{H}$ NMR 1.754 (d, 3H, $\left.J 7.4, \mathrm{CH}_{3}\right), 4.751$ (q, $1 \mathrm{H}, J$ 7.4, $\mathrm{CH}-\mathrm{CH}_{3}$ ), 6.578 (td, $1 \mathrm{H}, J 1.2,6.9, \mathrm{CH}-6$ ), 7.145 (ddd, $1 \mathrm{H}, J$ 1.2, 6.8, 9.0, $\mathrm{CH}-7$ ), 7.249 (dd, 1H, $J 1.7,8.5, \mathrm{CH}$ of Npt), 7.441 (dt, $1 \mathrm{H}, J 1.6,7.7, \mathrm{CH}$ of Npt), 7.467 (dt, 1H, $J 1.4$, 6.8, $\mathrm{CH}$ of Npt), 7.494 (d, 1H, J 7.5, CH of Npt), 7.506 (d, 1H, J 7.0, CH of Npt), 7.520 (d, 1H, $J$ 7.1, $\mathrm{CH}$ of Npt), $7.643(\mathrm{dd}, 1 \mathrm{H}, J 1.1,7.0, \mathrm{CH}-2$ of Npt-2), $7.697(\mathrm{~m}, 3 \mathrm{H}, \mathrm{CH}-8$ and $2 \mathrm{CH}$ of $\mathrm{Npt}), 7.727$ (dt, 1H, J, 1.1, 7.0, CH-5), $7.753(\mathrm{~d}, 1 \mathrm{H}, J$ 8.0, CH of Npt), 7.768 (d, 1H, J 8.3, CH of Npt), 7.902 (m, 2H, $2 \mathrm{CH}$ of Npt), 8.028 (dd, $1 \mathrm{H}, J 1.0,8.0, \mathrm{CH}$ of Npt). ${ }^{13} \mathrm{C}$ NMR 17.56 $\left(\mathrm{CH}_{3}\right), 34.70\left(\mathrm{CH}-\mathrm{CH}_{3}\right), 111.91(\mathrm{CH}-6), 117.90(\mathrm{CH}-8), 123.97(\mathrm{CH}-7), 124.36(\mathrm{CH}-5), 124.57$ $\left(C_{\text {quat }}-3\right), 124.90(\mathrm{CH}$ of Npt), $125.02(\mathrm{CH}$ of Npt), $125.82(\mathrm{CH}$ of $\mathrm{Npt}), 125.85(\mathrm{CH}$ of $\mathrm{Npt})$, $125.91(\mathrm{CH}$ of Npt),126.27 ( $\mathrm{CH}$ of Npt), $126.39(\mathrm{CH}$ of Npt), $126.55(\mathrm{CH}$ of Npt), $127.62(\mathrm{CH}$ of Npt), 127.82 ( $\mathrm{CH}$ of Npt), 128.15 ( $\mathrm{CH}$ of Npt), 128.32 ( $\mathrm{CH}$ of $\mathrm{Npt}), 128.59$ ( $\mathrm{CH}$ of $\mathrm{Npt}$ ), $128.69\left(C \mathrm{H}\right.$ of Npt), 132.23 ( $C_{\text {quat }}$ of Npt), 132.66 ( $C_{\text {quat }}$ of Npt), $133.26\left(C_{\text {quat }}\right.$ of $\left.\mathrm{Npt}_{\mathrm{t}}\right), 133.45$ $\left(C_{\text {quat }}\right.$ of Npt), 139.07 ( $C_{\text {quat }}-1$ of Npt-3), $143.07\left(C_{\text {quat }}-2\right), 144.81\left(C_{\text {quat }}-9\right)$; HRMS (EI): calcd. for $\mathrm{C}_{29} \mathrm{H}_{22} \mathrm{~N}_{2}\left(\mathrm{M}^{+}\right) 398.1778$, found 398.1772, -1.4 ppm error.

2-(4-Methoxyphenyl)-3-(1-(4-methoxyphenyl)ethyl)imidazo[1,2-a]pyridine $\quad(3 e) . \quad R_{\mathrm{f}} \quad 0.27$ (acetone: $\mathrm{CH}_{2} \mathrm{Cl}_{2}$ 10:90); mp 109.1-109.3 ${ }^{\circ} \mathrm{C} .{ }^{1} \mathrm{H}$ NMR 1.774 (d, 3H, J 7.4, $\mathrm{CH}_{3}$ ), 3.776 (s, 3H, $\mathrm{OCH}_{3}$ of 4-MeOPh-3), 3.848 (s, 3H, $\mathrm{OCH}_{3}$ of 4-MeOPh-2), 4.928 (q, 1H, J 7.4, $\mathrm{CH}-\mathrm{CH}_{3}$ ), 6.559 (td, $1 \mathrm{H}, J$ 1.2, 6.8, $\mathrm{CH}-6$ ), 6.838 (dt, 2H, $J$ 2.1, 8.8, $\mathrm{CH}-3$ and $\mathrm{CH}-5$ of 4-MeOPh-3), 6.991 (dt, $2 \mathrm{H}, J$ 2.2, 8.8, $\mathrm{CH}-3$ and $\mathrm{CH}-5$ of 4-MeOPh-2), 7.099 (ddd, $1 \mathrm{H}, J$ 1.3, 6.7, 9.0, $\mathrm{CH}-7$ ), 7.146 (dd, $2 \mathrm{H}, J$ 0.9, 8.9, $\mathrm{CH}-2$ and $\mathrm{CH}-6$ of 4-MeOPh-3), 7.601 (dt, $1 \mathrm{H}, J 1.1,6.9, \mathrm{CH}-5), 7.626$ (dt, $1 \mathrm{H}, J$ 1.1, 9.0, $\mathrm{CH}-8$ ), 7.668 (dd, $2 \mathrm{H}, \mathrm{J} 2.2,8.9, \mathrm{CH}-2$ and $\mathrm{CH}-6$ of $4-\mathrm{MeOPh}-2) .{ }^{13} \mathrm{C}$ NMR 16.88 $\left(\mathrm{CH}_{3}\right), 33.08\left(\mathrm{CH}-\mathrm{CH}_{3}\right), 55.27\left(\mathrm{OCH}_{3}\right.$ of $\left.4-\mathrm{MeOPh}-3\right), 55.33\left(\mathrm{OCH}_{3}\right.$ of $\left.4-\mathrm{MeOPh}-2\right), 111.50$ (CH-6), 113.95 ( $\mathrm{CH}-3$ and $\mathrm{CH}-5$ of 4-MeOPh-2), 114.17 ( $\mathrm{CH}-3$ and $\mathrm{CH}-5$ of 4-MeOPh-3), $117.58(\mathrm{CH}-8), 122.73\left(C_{\text {quat }}-3\right), 123.68(\mathrm{CH}-7), 124.60(\mathrm{CH}-5), 127.52$ ( $C_{\text {quat }}-1$ of $\left.4-\mathrm{MeOPh}-2\right)$, $127.87(\mathrm{CH}-2$ and $\mathrm{CH}-6$ of $4-\mathrm{MeOPh}-3), 130.10(\mathrm{CH}-2$ and $\mathrm{CH}-6$ of $4-\mathrm{MeOPh}-2), 133.10\left(C_{\text {quat }^{-}}\right.$ 1 of 4-MeOPh-3), $143.38\left(C_{\text {quat }}-2\right), 144.77\left(C_{\text {quat }}-9\right), 158.22$ ( $C_{\text {quat }}-4$ of $\left.4-\mathrm{MeOPh}-3\right), 159.32$ ( $C_{\text {quat }}-4$ of 4-MeOPh-2); HRMS (EI): calcd. for $\mathrm{C}_{23} \mathrm{H}_{22} \mathrm{~N}_{2} \mathrm{O}_{2}\left(\mathrm{M}^{+}\right)$358.1676, found 358.1680, 1.0 ppm error.

2-(4-Phenyl)-3-(1-(4-phenyl)vinyl)imidazo[1,2-a]pyridine (4a). $\mathrm{R}_{\mathrm{f}} \quad 0.45$ (acetone: $\mathrm{CH}_{2} \mathrm{Cl}_{2}$ 5:95), $\mathrm{R}_{\mathrm{f}} 0.63$ (acetone: $\mathrm{CH}_{2} \mathrm{Cl}_{2}$ 10:90); mp 123.6-123.9 ${ }^{\circ} \mathrm{C} .{ }^{1} \mathrm{H}$ NMR 5.580 (d, $1 \mathrm{H}, J ~ 0.9,1 / 2$ of $\mathrm{CH}_{2}=$ ), 6.170 (d, $1 \mathrm{H}, J 0.9,1 / 2$ of $\mathrm{CH}_{2}=$ ), 6.653 (dtd, $1 \mathrm{H}, J 1.1,6.8, \mathrm{CH}-6$ ), 7.177 (ddd, $1 \mathrm{H}, J$ 1.1, 6.7, 9.0, CH-7), 7.264 (tt, $1 \mathrm{H}, J$ 1.3 , 7.3, CH-4 of Ph-2), 7.333 (m, 5H, CH-3 and $\mathrm{CH}-5$ of Ph-2 and $\mathrm{CH}-3, \mathrm{CH}-4$ and $\mathrm{CH}-5$ of $\mathrm{Ph}-3$ ), 7.387 (dt, 2H, J 1.3, 7.0, $\mathrm{CH}-2$ and $\mathrm{CH}-6$ of Ph-3), 7.634 (dt, $1 \mathrm{H}, J 1.1,6.9, \mathrm{CH}-5), 7.685$ (dt, $1 \mathrm{H}, J 1.0,9.0, \mathrm{CH}-8), 7.934$ (dt, 2H, $J 1.9,7.1, \mathrm{CH}-2$ and $\mathrm{CH}-6$ of Ph-2). ${ }^{13} \mathrm{C}$ NMR 112.24 (CH-6), $117.35(\mathrm{CH}-8), 120.12\left(\mathrm{C}_{\text {quat }}-3\right), 121.42\left(\mathrm{CH}_{2}=\right)$, 124.28 ( $\mathrm{CH}-5), 124.71(\mathrm{CH}-7), 126.17$ ( $\mathrm{CH}-2$ and $\mathrm{CH}-6$ of Ph-3), $127.63(\mathrm{CH}-4$ of Ph-2), 127.88 $(\mathrm{CH}-2$ and $\mathrm{CH}-6$ of $\mathrm{Ph}-2), 128.32(\mathrm{CH}-3$ and $\mathrm{CH}-5 \mathrm{of} \mathrm{Ph}), 128.78(\mathrm{CH}-4 \mathrm{of} \mathrm{Ph}-3), 129.06(\mathrm{CH}-3$ and $C \mathrm{H}-5$ of $\mathrm{Ph}), 133.93$ ( $C_{\text {quat }}-1$ of Ph-2), $137.58\left(C_{\text {quat }}=\right.$ and $C_{\text {quat }}-1$ of Ph-3), $143.37\left(C_{\text {quat }}-2\right)$, 
$144.81\left(C_{\text {quat }}-9\right)$; HRMS (EI): calcd. for $\mathrm{C}_{21} \mathrm{H}_{16} \mathrm{~N}_{2}\left(\mathrm{M}^{+}\right)$296.1308, found 296.1301, -2.5 ppm error.

2-(4-Methoxyphenyl)-3-(1-(4-methoxyphenyl)vinyl)imidazo[1,2-a]pyridine $\quad(4 e) . \quad R_{f} \quad 0.30$ (acetone: $\mathrm{CH}_{2} \mathrm{Cl}_{2}$ 5:95), $\mathrm{R}_{\mathrm{f}} 0.44$ (acetone: $\mathrm{CH}_{2} \mathrm{Cl}_{2}$ 10:90); ${ }^{1} \mathrm{H} \mathrm{NMR} 3.809$ (s, 3H, OCH of 4MeOPh-3), 3.824 (s, 3H, OCH $H_{3}$ of 4-MeOPh-2), 5.485 (d, $1 \mathrm{H}, J$ 0.8, 1/2 of $\left.\mathrm{CH}_{2}=\right), 6.087$ (d, $1 \mathrm{H}, J$ $0.8,1 / 2$ of $\left.\mathrm{CH}_{2}=\right), 6.660(\mathrm{td}, 1 \mathrm{H}, J 1.2,6.7, \mathrm{CH}-6), 6.863(\mathrm{dt}, 2 \mathrm{H}, J 2.1,8.9, \mathrm{CH}-3$ and $\mathrm{CH}-5$ of 4MeOPh-3), 6.898 (dt, 2H, J 2.1, 8.9, CH-3 and CH-5 of 4-MeOPh-2), 7.174 (ddd, 1H, J 0.9, 6.7, 9.2, $\mathrm{CH}-7$ ), 7.330 (dt, 2H, J 2.1, 8.9, CH-2 and $\mathrm{CH}-6$ of 4-MeOPh-3), 7.668 (m, 2H, CH-5 and $\mathrm{CH}-8), 7.903$ (dt, 2H, J 2.1, 8.9, $\mathrm{CH}-2$ and $\mathrm{CH}-6$ of 4-MeOPh-2). ${ }^{13} \mathrm{C} \mathrm{NMR} 55.23\left(\mathrm{OCH}_{3}\right.$ of 4MeOPh-3), 55.33 ( $\mathrm{OCH}_{3}$ of 4-MeOPh-2), 111.99 (CH-6), 113.76 ( $\mathrm{CH}-3$ and $\mathrm{CH}-5$ of 4-MeOPh2), 114.37 ( $\mathrm{CH}-3$ and $\mathrm{CH}-5$ of 4-MeOPh-3), $117.12(\mathrm{CH}-8), 119.10\left(\mathrm{CH}_{2}=\right), 119.54\left(C_{\text {quat }}-3\right)$, 124.23 (CH-5), 124.41 ( $\mathrm{CH}-7), 126.75$ ( $\mathrm{C}_{\text {quat }}{ }^{-1}$ of 4-MeOPh-2), $127.48(\mathrm{CH}-2$ and $\mathrm{CH}-6$ of $4-$ MeOPh-3), 129.06 ( $\mathrm{CH}-2$ and $\mathrm{CH}-6$ of 4-MeOPh-2), 130.11 ( $C_{\text {quat }}-1$ of 4-MeOPh-3), 137.17 $\left(C_{\text {quat }}=\right), 143.12\left(C_{\text {quat }}-2\right), 144.80\left(C_{\text {quat }}-9\right), 159.20\left(C_{\text {quat }}-4\right.$ of $\left.4-\mathrm{MeOPh}-2\right), 160.08\left(C_{\text {quat }}-4\right.$ of $4-$ MeOPh-3); HRMS (EI): calcd. for $\mathrm{C}_{23} \mathrm{H}_{20} \mathrm{~N}_{2} \mathrm{O}_{2}\left(\mathrm{M}^{+}\right)$356.1519, found 356.1518, -0.4 ppm error.

2-(4-Nitrophenyl)-3-(1-(4-nitrophenyl)vinyl)imidazo[1,2-a $]$ pyridine $\quad(\mathbf{4 f}) . \quad \mathrm{R}_{\mathrm{f}} \quad 0.56$ (acetone: $\mathrm{CH}_{2} \mathrm{Cl}_{2}$ 5:95), $\mathrm{R}_{\mathrm{f}} 0.76$ (acetone: $\mathrm{CH}_{2} \mathrm{Cl}_{2}$ 10:90); mp 178.7-178.9 ${ }^{\circ} \mathrm{C}$ (decomp.). ${ }^{1} \mathrm{H} \mathrm{NMR}$ 5.889 (s, $1 \mathrm{H}, 1 / 2$ of $\left.\mathrm{CH}_{2}=\right), 6.473$ (s, $1 \mathrm{H}, 1 / 2$ of $\mathrm{CH}_{2}=$ ), 6.821 (ddd, $1 \mathrm{H}, J$ 1.0, 6.7, 7.1, CH-6), 7.316 (ddd, $1 \mathrm{H}, J$ 1.1, 6.7, 9.1, CH-7), 7.528 (dt, 2H, $J$ 2.0, 9.0, $\mathrm{CH}-2$ and $\mathrm{CH}-6$ of 4-NO $\mathrm{Nh}_{2} \mathrm{Ph}$ ), 7.728 (dd, 1H, J 1.0, 9.1, CH-8), 7.738 (dd, 1H, J 1.1, 7.1, CH-5), 8.039 (dt, 2H, J 2.0, 9.0, CH-2 and $\mathrm{CH}-6$ of $\left.4-\mathrm{NO}_{2} \mathrm{Ph}-2\right), 8.176\left(\mathrm{dt}, 2 \mathrm{H}, J\right.$ 2.0, 9.0, $\mathrm{CH}-3$ and $\mathrm{CH}-5$ of $\left.4-\mathrm{NO}_{2} \mathrm{Ph}-2\right), 8.193$ (dt, 2H, $J$ 2.0, 9.0, $\mathrm{CH}-3$ and $\mathrm{CH}-5$ of $\left.4-\mathrm{NO}_{2} \mathrm{Ph}-3\right) .{ }^{13} \mathrm{C}$ NMR $113.56(\mathrm{CH}-6), 117.95(\mathrm{CH}-8), 120.34$ $\left(C_{\text {quat }}-3\right), 123.83\left(\mathrm{CH}-3\right.$ and $\mathrm{CH}-5$ of $\left.4-\mathrm{NO}_{2} \mathrm{Ph}-2\right), 123.90(\mathrm{CH}-5), 124.54(\mathrm{CH}-3$ and $\mathrm{CH}-5$ of $4-$ $\left.\mathrm{NO}_{2} \mathrm{Ph}-3\right), 125.69\left(\mathrm{CH}_{2}=\right), 126.23(\mathrm{CH}-7), 126.96\left(\mathrm{CH}-2\right.$ and $\mathrm{CH}-6$ of $\left.4-\mathrm{NO}_{2} \mathrm{Ph}-3\right), 128.22(\mathrm{CH}-$ 2 and $C \mathrm{H}-6$ of $\left.4-\mathrm{NO}_{2} \mathrm{Ph}-2\right), 135.76\left(C_{\text {quat }}=\right), 139.99\left(C_{\text {quat }}-1\right.$ of $\left.4-\mathrm{NO}_{2} \mathrm{Ph}-2\right), 141.17\left(C_{\text {quat }}-2\right)$, $143.35\left(C_{\text {quat }}-1\right.$ of $\left.4-\mathrm{NO}_{2} \mathrm{Ph}-3\right), 145.45\left(C_{\text {quat }}-9\right), 147.10\left(C_{\text {quat }^{-}}-4\right.$ of $\left.4-\mathrm{NO}_{2} \mathrm{Ph}-2\right), 148.08\left(C_{\text {quat }^{-4}}\right.$ of 4-NO $\left.\mathrm{NO}_{2} \mathrm{Ph}-3\right)$; HRMS (EI): calcd. for $\mathrm{C}_{21} \mathrm{H}_{14} \mathrm{~N}_{4} \mathrm{O}_{4}\left(\mathrm{M}^{+}\right)$386.1010, found 386.1017, $1.8 \mathrm{ppm}$ error.

2-(4-Methoxyphenyl)imidazo[1,2-a]pyridine (5e). $\mathrm{R}_{\mathrm{f}} 0.32$ (acetone: $\mathrm{CH}_{2} \mathrm{Cl}_{2}$ 10:90); mp 129.4129.6 ${ }^{\circ} \mathrm{C}$. ${ }^{1} \mathrm{H}$ NMR 3.862 (s, 3H, OCH $\mathrm{OH}_{3}$ 4-MeOPh), 6.748 (td, 1H, J 1.1, 6.7, CH-6), 6.988 (dt, $2 \mathrm{H}, J$ 2.1, 8.9, $\mathrm{CH}-3$ and $\mathrm{CH}-5$ of 4-MeOPh), 7.152 (ddd, $1 \mathrm{H}, J$ 1.3, 6.7, 9.0, CH-7), 7.620 (dd, $1 \mathrm{H}, J$ 0.9, 9.0, CH-8), 7.764 (d, 1H, $J$ 0.5, CH-3), 7.901 (dt, 2H, $J$ 2.1, 8.9, CH-2 and $\mathrm{CH}-6$ of 4$\mathrm{MeOPh}), 8.081$ (dt, $1 \mathrm{H}, J$ 1.1, 6.8, $\mathrm{CH}-5) .{ }^{13} \mathrm{C} \mathrm{NMR} 55.33\left(\mathrm{OCH}_{3}\right.$ of 4-MeOPh), $107.26(\mathrm{CH}-3)$, 112.25 (CH-6), 114.15 (CH-3 and $C H-5$ of 4-MeOPh), 117.28 (CH-8), 124.47 (CH-7), 125.49 $(C H-5), 126.50\left(C_{\text {quat }}-1\right.$ of $\left.4-\mathrm{MeOPh}\right), 127.30(\mathrm{CH}-2$ and $C \mathrm{H}-6$ of $4-\mathrm{MeOPh}), 145.63\left(C_{\text {quat }}{ }^{-9}\right)$, $145.72\left(C_{\text {quat }}-2\right), 159.58\left(C_{\text {quat }}-4\right.$ of $\left.4-\mathrm{MeOPh}\right)$; HRMS $(\mathrm{EI})$ : calcd. for $\mathrm{C}_{14} \mathrm{H}_{12} \mathrm{~N}_{2} \mathrm{O}\left(\mathrm{M}^{+}\right)$ 224.0944, found 224.0941, -1.4 ppm error.

4-Methyl-2,4-bis(4-nitrophenyl)-4H-pyrido[1,2-a]pyrimidine (6f). $\mathrm{R}_{\mathrm{f}} 0.24$ (acetone: $\mathrm{CH}_{2} \mathrm{Cl}_{2}$ 50:50); mp 148.6-148.8 ${ }^{\circ} \mathrm{C}$ (decomp.). ${ }^{1} \mathrm{H}$ NMR 2.111 (s, 3H, $\mathrm{CH}_{3}$ ), 5.106 (s, 1H, CH-3), 6.039 (ddd, 1H, J 1.4, 6.4, 7.1, CH-7), 6.723 (dd, 1H, J 1.4, 9.1, CH-9), 6.743 (dd, 1H, J 1.5, 7.1, CH- 
6), 6.962 (ddd, $1 \mathrm{H}, J$ 1.5, 6.4, 9.1, $\mathrm{CH}-8), 7.636$ (tt, $2 \mathrm{H}, J 1.9,8.9, \mathrm{CH}-2$ and $\mathrm{CH}-6$ of $4-\mathrm{NO}_{2} \mathrm{Ph}-$ 4), 7.834 (tt, $2 \mathrm{H}, J$ 1.9, 8.9, $\mathrm{CH}-2$ and $\mathrm{CH}-6$ of $\left.4-\mathrm{NO}_{2} \mathrm{Ph}-2\right), 8.093$ (tt, $2 \mathrm{H}, J 1.9,8.9, \mathrm{CH}-3$ and $\mathrm{CH}-5$ of $\left.4-\mathrm{NO}_{2} \mathrm{Ph}-2\right), 8.173$ (tt, $2 \mathrm{H}, J$ 1.9, 8.9, $\mathrm{CH}-3$ and $\mathrm{CH}-5$ of $\left.4-\mathrm{NO}_{2} \mathrm{Ph}-4\right) .{ }^{13} \mathrm{C}$ NMR 29.32 $\left(\mathrm{CH}_{3}\right), 64.90\left(\mathrm{C}_{\text {quat }}-4\right), 105.05(\mathrm{CH}-3), 110.05(\mathrm{CH}-7), 123.44\left(\mathrm{CH}-3\right.$ and $\mathrm{CH}-5$ of $\left.4-\mathrm{NO}_{2} \mathrm{Ph}-2\right)$, 124.16 ( $\mathrm{CH}-3$ and $\mathrm{CH}-5$ of $\left.4-\mathrm{NO}_{2} \mathrm{Ph}-4\right), 124.83$ ( $\left.\mathrm{CH}-9\right), 126.39$ ( $\mathrm{CH}-2$ and $\mathrm{CH}-6$ of 4-NO $\left.{ }_{2} \mathrm{Ph}-2\right)$, $127.35\left(\mathrm{CH}-2\right.$ and $\mathrm{CH}-6$ of $\left.4-\mathrm{NO}_{2} \mathrm{Ph}-4\right), 133.47(\mathrm{CH}-6), 134.71(\mathrm{CH}-8), 140.11\left(C_{\text {quat }}-4\right.$ of $4-$ $\left.\mathrm{NO}_{2} \mathrm{Ph}-2\right), 144.89\left(C_{\text {quat }}-1\right.$ of $\left.4-\mathrm{NO}_{2} \mathrm{Ph}-2\right), 147.33\left(C_{\text {quat }}-4\right.$ of $\left.4-\mathrm{NO}_{2} \mathrm{Ph}-4\right), 147.41\left(C_{\text {quat }}-2\right)$, $151.48\left(C_{\text {quat }}-10\right), 152.87\left(C_{\text {quat }}-1\right.$ of $\left.4-\mathrm{NO}_{2} \mathrm{Ph}-4\right)$; HRMS (EI): calcd. for $\mathrm{C}_{21} \mathrm{H}_{16} \mathrm{~N}_{4} \mathrm{O}_{4}\left(\mathrm{M}^{+}\right)$ 388.1170, found 388.1166, 1.0 ppm error.

\section{Crystallography}

The crystals of 3a, 4a and 5e were mounted of on a glass capillary and all geometric and intensity data were taken from these crystals. Data collection using Mo- $\mathrm{K}_{\alpha}$ radiation $(\lambda=0.71073$ $\AA$ ) was performed at room temperature on an Oxford diffraction Supernova diffractometer. The crystal data $^{19}$ are collected on Table S1 (Supplementary Material). The structures were solved with SHELXS-97 and refined using full-matrix least-squares on $F^{2}$ with the SHELXL-97 package. $^{20}$

\section{Supplementary Material}

The description of 2D NMR spectra of the products and the crystallographic data are given in the Supplementary Material.

\section{Acknowledgements}

The financial support by The Bulgarian Science Fund, projects UNA-17/2005, DRNF-0213/2009, DRNF-02/01 and BG051PO001/3.3-05 "Science \& Business" DO2-546, is gratefully acknowledged.

\section{References}

1. (a) Gueiffier, A.; Lhassani, M.; Elhakmaoui, A.; Snoeck, R.; Andrei, G.; Chavignon, O.; Teulade, J.-C.; Kerbal, A.; Essassi, E. M.; Debouzy, J.-C.; Witvrouw, M.; Blache, Y.; Balzarini, J.; De Clercq, E.; Chapat, J.-P. J. Med. Chem. 1996, 39, 2856-2859. (b) Gudmundsson, K. S.; Johns, B. A. Bioorg. Med. Chem. Lett. 2007, 17, 2735-2739. (c) Bode, M. L.; Gravestock, D.; Moleele, S. S.; van der Westhuyzen, C. W.; Pelly, S. C.; Steenkamp, P. A.; Hoppe, H. C.; Khan, T.; Nkabinde, L. A. Bioorg. Med. Chem. 2011, 19, 4227-4237. 
2. (a) Rival, Y.; Grassy, G.; Michel, G. Chem. Pharm. Bull. 1992, 40, 1170-1176. (b) Starr, J. T.; Sciotti, R. J.; Hanna, D. L.; Huband, M. D.; Mullins, L. M.; Cai, H.; Gage, J. W.; Lockard, M.; Rauckhorst, M. R.; Owen, R. M.; Lall, M. S.; Tomilo, M.; Chen, H.; McCurdy, S. P.; Barbachyn, M. R. Bioorg. Med. Chem. Lett. 2009, 19, 5302-5306. (c) Al-Tel, T. H.; Al-Qawasmeh, R. A.; Zaarour, R. Eur. J. Med. Chem. 2011, 46, 1874-1881.

3. (a) Jaramillo, C.; De Diego, J. E.; Hamdouchi, C.; Collins, E.; Keyser, H.; Sanchez-Martinez, C.; Del Prado, M.; Norman, B.; Brooks, H. B.; Watkins, S. A.; Spencer, C. D.; Dempsey, J. A.; Anderson, B. D.; Campbell, R. M.; Leggett, T.; Patel, B.; Schultz, R. M.; Espinosa, J.; Vieth, M.; Zhang, F.; Timm, D. E. Bioorg. Med. Chem. Lett. 2004, 14, 6095-6099. (b) Hayakawa, M.; Kaizawa, H.; Kawaguchi, K.-i.; Ishikawa, N.; Koizumi, T.; Ohishi, T.; Yamano, M.; Okada, M.; Ohta, M.; Tsukamoto, S.-i.; Raynaud, F. I.; Waterfield, M. D.; Parker, P.; Workman, P. Bioorg. Med. Chem. 2007, 15, 403-412. (c) Kamal, A.; Ramakrishna, G.; Raju, P.; Rao, A. V. S.; Viswanath, A.; Nayak, V. L.; S. Ramakrishna, Eur. J. Med. Chem. 2011, 46, 2427-2435.

4. (a) Sacchi, A.; Laneri, S.; Arena, F.; Luraschi, E.; Attignente, E.; Arnico, M. D.; Berrino, L.; Rossi, F. Eur. J. Med. Chem. 1997, 32, 677-682. (b) Lacerda, R. B.; de Lima, C. K. F.; da Silva, L. L.; Romeiro, N. C.; Miranda, A. L. P.; Barreiro, E. J.; Fraga, C. A. M. Bioorg. Med. Chem. 2009, 17, 74-84.

5. (a) Scribner, A.; Dennis, R.; Hong, J.; Lee, S.; McIntyre, D.; Perrey, D.; Feng, D.; Fisher, M.; Wyvratt, M.; Leavitt, M.; Liberator, P.; Gurnett, A.; Brown, C.; Mathew, J.; Thompson, D.; Schmatz, D.; Biftu, T. Eur. J. Med. Chem. 2007, 42, 1334-1357. (b) Scribner, A.; Dennis, R.; Lee, S.; Ouvry, G.; Perrey, D.; Fisher, M.; Wyvratt, M.; Leavitt, P.; Liberator, P.; Gurnett, A.; Brown, C.; Mathew, J.; Thompson, D.; Schmatz, D.; Biftu, T. Eur. J. Med. Chem. 2008, 43, 1123-1151. (c) López-Martínez, M.; Salgado-Zamora, H.; Campos-Aldrete, M. E.; Trujillo-Ferrara, J. G.; Correa-Basurto, J.; Mexica-Ochoa, C. Med. Chem. Res. 2012, 21, 415420.

6. (a) Nicholson, A. N.; Pascoe, P. A. Br. J. Clin. Pharmac. 1986, 21, 205-211. (b) Harrison, T. S.; Keating, G. M. CNS Drugs 2005, 19, 65-89. (c) Monti, J. M.; Spence, D. W.; PandiPerumal, S. R.; Langer, S. Z.; Hardeland, R. Clin. Med. Ther. 2009, 1, 123-140.

7. (a) Bonnet, P. A.; Michel, A.; Laurent, F.; Sablayrolles, C.; Rechencq, E.; Mani, J. C.; Boucard, M.; Chapat J. P. J. Med. Chem. 1992, 35, 3353-3358. (b) Hamdouchi, C.; de Blas, J.; del Prado, M.; Gruber, J.; Heinz, B. A.; Vance, L. J. Med. Chem. 1999, 42, 50-59.

8. (a) Chunavala, K. C.; Joshi, G.; Suresh, E.; Adimurthy, S. Synthesis 2011, 635-641. (b) Harris, A. R.; Nason, D. M.; Collantes, E. M.; Xu, W.; Chi, Y.; Wang, Z.; Zhang, B.; Zhang, Q.; Gray, D. L.; Davoren, J. E. Tetrahedron 2011, 67, 9063-9066.

9. Yadav, J. S.; Reddy, B. V. S.; Rao, Y. G.; Srinivas, M.; Narsaiah, A. V. Tetrahedron Lett. 2007, 48, 7717-7720.

10. Britsun, V. N.; Borisevich, A. N.; Pirozhenko, V. B.; Lozinskii, M. O. Russ. J. Org. Chem. 2007, 43, 276-279.

11. Kondo, T.; Kotachi, S.; Ogino, S.-I.; Watanabe, Y. Chem. Lett. 1993, 1317-1320. 
12. Katritzky, A. R.; Qiu, G.; Long, Q.; He, H.; Steel, P. J. J. Org. Chem. 2000, 65, 9201-9205.

13. Katritzky, A. R.; Xu, Y.-J.; Tu, H. J. Org. Chem. 2003, 68, 4935-4937.

14. (a) Bienaymé, H.; Bouzid, K. Angew. Chem. Int. Ed. 1998, 37, 2234-2237. (b) DiMauro, E. F.; Kennedy, J. M. J. Org. Chem. 2007, 72, 1013-1016.

15. (a) Rousseau, A. L.; Matlaba, P.; Parkinson, C. J. Tetrahedron Lett. 2007, 48, 4079-4082. (b) Akbarzadeh, R.; Shakibaei, G. I.; Bazgir, A. Monatsh. Chem. 2010, 141, 1077-1081.

16. Kianmehr, E.; Ghanbari, M.; Niri, M. N.; Faramarzi, R. J. Comb. Chem. 2010, 12, 41-44.

17. (a) Liu, P.; Fang, L.-S.; Lei, X.; Lin, G.-Q. Tetrahedron Lett. 2010, 51, 4605-4608. (b)

Reddy, B. V. S.; Reddy, P. S.; Reddy, Y. J.; Yadav, J. S. Tetrahedron Lett. 2011, 52, 57895793.

18. (a) Moutou, J.-L.; Schmitt, M.; Collot, V.; Bourguignon, J.-J. Heterocycles 1997, 45, 897910. (b) Basilio-Lopes, A.; Mendonça de Aquino, T.; Mongeot, A.; Bourguignon, J.-J.; Schmitt, M. Tetrahedron Lett. 2012, 53, 2583-2587.

19. The crystallographic data for the products of $\mathbf{3 a}, \mathbf{4 a}$ and $\mathbf{5 e}$ were deposited at the Cambridge Crystallographic Data Centre and allocated the deposition numbers CCDC 846146, CCDC 871761 and CCDC 847911, respectively. Copies of the data can be obtained, free of charge, on application to CCDC, 12 Union Road, Cambridge CB2 1EZ, UK; tel: +44 1223 762910; fax: +44 1223 336033; e-mail: deposit@ccdc.cam.ac.uk; http://www.ccdc.cam.ac.uk/deposit. 20. Sheldrick, G. M. Acta Cryst. A. 2008, 64, 112-122. 